Water, Air, \& Soil Pollution 223 (2012) pp.5613-5622

\title{
Winter time concentrations and size distribution of bioaerosols in different residential settings in the UK
}

Zaheer Ahmad Nasir ${ }^{1 \dagger}$ and Ian Colbeck ${ }^{1 *}$

${ }^{1}$ Department of Biological Sciences, University of Essex, Colchester, CO4 3SQ, U K

¥ Current address: University College London, Healthy Infrastructure Research Group, Department of Civil, Environmental and Geomantic Engineering. WC1E 6BT

*Corresponding author: E-mail: colbi@essex.ac.uk, Tel +44-1206-872203, Fax: +44-1206872592

\begin{abstract}
The total concentration and size distribution of bioaerosols in three different types of housing (single room in shared accommodation (type I), single bedroom flat in three storey building (type II) and two or three bedroom detached houses (type III)) was assessed during the winter. This research was an extension of a previous study carried out in the summer. The measurement campaign was undertaken in winter 2008 and thirty houses were sampled. Samples were taken from kitchens, living rooms, corridors (only in housing type I) and outdoors with an Anderson 6 stage viable impactor. In housing type I the total geometric mean concentration was highest in the corridor for both bacteria and fungi $\left(3171 \mathrm{CFU} / \mathrm{m}^{3}, 1281 \mathrm{CFU} / \mathrm{m}^{3}\right)$. In type II residences both culturable bacteria and fungi were greatest in the living rooms $\left(3487 \mathrm{CFU} / \mathrm{m}^{3}, 833 \mathrm{CFU} / \mathrm{m}^{3}\right)$. The living rooms in type III residences had largest number of culturable bacteria $\left(1361 \mathrm{CFU} / \mathrm{m}^{3}\right)$ while fungi were highest in kitchens $\left(280 \mathrm{CFU} / \mathrm{m}^{3}\right)$. The concentrations of culturable bacteria and fungi were greater in mouldy houses than non-mouldy houses. A considerable variation was seen in the size distribution of culturable bacteria in type I residences compared to types II and III. For all housing types more than half of culturable bacterial and fungal aerosol were respirable $(<4.7 \mu \mathrm{m})$ and so have the potential to penetrate into lower respiratory system. Considerable variation in concentration and size distribution within different housing types in the same geographical region highlights the impact of differences in design, construction, use and management of residential built environment on bioaerosols levels and consequent varied risk of population exposure to airborne biological agents.
\end{abstract}

\section{Keywords: Indoor air quality, Bioaerosols, Size distribution}

\section{Introduction}

Bioaerosols have drawn considerable attention with regard to indoor air quality due to their toxigenic, allergenic and/or infectious potential. Recent air quality guidelines on dampness and 
mould by the World Health Organization (2009) concluded that there is sufficient epidemiological evidence that the inhabitants of both damp or mouldy houses and public buildings are at increased risk of respiratory symptoms, respiratory infections and exacerbation of asthma. Bioaerosols can range in size from 20 to $300 \mathrm{~nm}$ for viruses, 0.2 to $30 \mu \mathrm{m}$ for bacterial cells and spores and between 10 and $100 \mu \mathrm{m}$ for pollens and plant spores (Morris 1995). They can consist of single cells, aggregates of cells or fragments carried by other materials such as respiratory secretion, water droplets, skin flakes or dust particles. Once aerosolized, their size, depending on the carrier matrix, may change due to different environmental factors (relative humidity and temperature).

A number of studies have been carried out to investigate the level of bioaerosols in indoor residential settings in different geographical regions (Dekoster and Thorne, 1995; Gorny and Dutkiewicz., 2002; Green et al., 2003; Hass et al., 2007; Hunter et al., 1996; Hyvarinen et al., 2001; Kalogerakis et al., 2005; Lee et al., 2006; Lee and Jo, 2006; Mentese et al., 2009; Nasir and Colbeck, 2010; Nevalainen et al., 1991; Pastuszka et al., 2000). In the United Kingdom studies have been reported by Hunter et al. (1988, 1996), Strachan et al. (1990) and Nasir and Colbeck (2010). Most of these studies have focused on total concentration, although knowledge of the size distribution is critical with regard to their airborne behavior and deposition in the human respiratory system.

Bioaerosols in indoor environments can be of both outdoor and indoor origin (Fabian et al. 2005) and a range of biotic and abiotic factors affect their concentration and size distribution. Outdoor bioaerosols can make their way into residential built environment through a range of avenues. For example, doors, windows, cracks in the walls, attached to people, pets and objects. It has been reported that bioaerosols vary with location, season, climate and time of the day (Hyvärinen et al., 2001; Levetin et al., 1995; Li and Kuo, 1993; Medrela-Kuder, 2003). It has also been reported that the moisture content of building material (Pasanen et al. 2000; Viitanen et al., 2000), outdoor concentrations, indoor /outdoor exchange rates (Kulmala et al., 1999), number of people and animals (ACGIH, 1999) and human activities (Buttner and Stetzenbach, 1993) affect the indoor concentration of bioaerosols. Once in the indoor environment, bioaersols can impact on different surfaces, accumulate, resuspend and may grow on various indoor surfaces depending 
on the availability of ecological niches. These factors vary greatly depending on housing type, construction material, geographic location and use and management of residential space by occupants and their building hygiene awareness. In developed countries a considerable amount of time is spent indoors and over the last two decades residential built environments have seen unprecedented changes in both design and construction materials. Investigations into bioaerosols in various types of residential settings can contribute significantly to enhance our understanding of the dynamics of indoor bioaerosol exposure. The work reported here is an extension of a previous study carried out in summer (Nasir and Colbeck, 2010) at a suburban site in southeast England. This paper presents details of the total concentration and size distribution of fungal and bacterial aerosol in three different types of housing during the winter, with the inclusion of more residences in each setting. Moreover, during the summer time the samples were only taken from living room but in the winter campaign, samples were collected from kitchens, living rooms, corridor (only in Type I) and outdoors.

\section{Materials and methods}

The measurement campaign was undertaken in winter 2008 and thirty houses were sampled. The details of housing types, building examination, sampling design, methods and data analysis are given in Nasir and Colbeck (2010). Briefly Type I houses were single rooms in shared accommodation, Type II consisted of single bedroom flats in three storey buildings while Type III were two or three bedroom houses. This investigation included the houses from the summer 2007 campaign and as well as 15 additional houses ( 3 in type I, 7 in type II and 5 in type III). Briefly, the samples were taken from kitchens, living rooms, corridors (only in housing type I) and outdoors in each housing type with an Anderson 6 stage viable impactor. During the summer campaign all the houses were without any visible mould while during the present (winter) campaign there were 2 houses with visible mould growth in both housing types II and III. The sampling interval was 2 minutes and Typtone Soy agar (Oxoid, UK) and Malt Extract agar (Oxoid, UK) was used as the impaction surface. The agar plates were incubated at $25^{\circ} \mathrm{C}$ for 48 hours in the case of bacteria and up to 7 days for fungi. Relative humidity and temperature in the different settings was recorded with a Gasprobe IAQ 4 (BW Technologies Ltd, Canada) with a logging interval of 1 minute. 
The number of colonies from each plate was enumerated, the total numbers of culturable colony forming units per cubic meter $\left(\mathrm{CFU} / \mathrm{m}^{3}\right)$ were calculated for each stage and total counts for all the stages made. The data was analyzed in terms of housing type and whether mould was visible or not. The normality of distribution of the concentrations in different settings was checked by the Shapiro-Wilk test. The distributions were lognormal and geometric means and geometric standard deviation were calculated for each size and total concentration for each housing type. Furthermore, the geometric mean diameter of each sample was calculated and average geometric mean diameter determined.

\section{Results and discussion}

\section{Total concentration of culturable bacteria and fungi}

The total geometric mean concentration of culturable bacteria in type I residences in the kitchens, living rooms, corridor and outdoors is shown in Table 1. Higher concentrations were seen in the corridor for both bacteria and fungi. However, bacteria were more abundant in the kitchen than in the living room. In the living room the concentration of fungi was slightly higher than culturable bacteria. The houses in this type consisted of student accommodation and the kitchen was shared by a minimum of 5 people. Higher concentrations in the corridor most probably reflect the contribution from occupant movement. The flooring of the corridor and living rooms was carpeted while that of kitchen was vinyl laminated.

In type II residences the total geometric mean concentration of both culturable bacteria and fungi was maximum in living rooms followed by kitchens and outdoors. In mouldy houses the concentrations of both culturable bacteria and fungi were greater than non-mouldy houses in the same category.

The living rooms in type III residences had maximum number of culturable bacteria. When mould was present, substantially higher concentrations of both culturable bacteria and fungi was found (Table 1). These elevated values of fungal and bacterial aerosol reflect the effects of microbial growth inside the houses. Hunter et al. (1988), Waegemakers et al. (1989) and Verhoeff et al. (1992) reported higher concentrations of fungi in houses with mould problems. Moisture and mould problems in buildings have been reported to increase the indoor air 
concentration of fungi (Hyvarinen et al. 1993; Meklin et al. 2003; Miller et al. 2000). Other studies have reported higher airborne fungal concentrations in moisture and mould problem buildings than in non-mouldy buildings (Gorny et al., 1999; Hyvärinen et al., 1993; Haas et al., 2007; Macher et al., 1991; Miller et al., 2000; Pessi et al., 2002; Salonen et al. 2007).

During the summer campaign (Nasir and Colbeck, 2010), concentrations of both bacterial and fungal aerosol were more than double in type III housing as compared to types I and II. In the winter campaign the concentrations of culture bacteria in the living rooms were higher in type II than types I and III while fungi was higher in type I than types II and III. Comparison of culturable bacteria and fungi in living rooms, in non-mouldy houses, during both campaigns revealed that the concentrations were higher in type I and II houses and lower in type III during the winter campaign. Furthermore the indoor concentration of both bacteria and fungi were higher than those outdoors for all the housing types. This indicates indoor sources of bioaerosols. Many studies have reported higher indoor levels in summer in non-mouldy houses (Hass et al., 2007; Lee and Jo, 2006; Pastuszka et al., 2000; Ren et al., 1999; Shelton et al., 2002;) due to the migration of fungal spores from outdoors. However, during the present study the concentrations were generally higher in winter than summer, except type III residences, which had higher levels of both bacteria $(\sim x 4)$ and fungi $(\sim x 7)$ in summer. Differences in the volume of residential spaces, ventilation behaviour, occupant density and life style among the different residential settings could be a likely reason for these discrepancies. The quantity of indoor furnishings, general household cleaning practices and ventilation behaviour will greatly affect the amount of aerosolized bioaerosols from already deposited particles on indoor surfaces and ingress of outdoor bioaerosols (ACGIH, 1999; Jones and Harrison, 2004).

\section{Temperature and relative humidity}

The indoor and outdoor temperature for all the housing types was reasonably uniform and ranged between $20-21^{\circ} \mathrm{C}$ and $12-13^{\circ} \mathrm{C}$. However, there was a large variation in relative humidity in all the housing types. In non-mouldy housing types I, II and III indoor relative humidity averaged $38 \%, 50 \%$ and $37 \%$, respectively (Table 2). In mouldy residences the relative humidity was higher $(60-66 \%)$. Although the indoor temperature was uniform during winter and summer campaigns, the relative humidity was highly variable and was generally lower in winter than 
summer. Relative humidity plays a major role in the survival of airborne microorganisms. An analysis of correlation between bacterial and fungal concentrations and relative humidity in three different types of housing showed that for housing Type I there was a very weak correlation for bacterial $(r=-0.085)$ and fungal aerosol concentration $(r=0.007)$. However, relative humidity was strongly correlated with both bacterial and fungal culture counts in housing types II $(\mathrm{r}=0.70$ and 0.87$)$ and III ( $\mathrm{r}=0.87$ and 0.81$)$ and these values were statistically significant. Outdoors, there was no significant relationship for bacterial and fungal concentrations with relative humidity ( $\mathrm{r}=0.11$ and 0.18 ). Raisi et al. (2010) have also reported a very weak correlation between bacterial or fungal concentrations and ambient meteorological parameters. The lack of any correlation in housing type $I$ is possibly the result a greater contribution of other building and human factors (e.g. degree of occupancy, activities/lifestyle, ventilation behaviour, ingress of particles from outdoor, furnishings, resuspension of deposited biological particles) to the culturable bioaerosol concentration. Type I houses were without any visible mould growth whereas in type II and III houses mould was present in some houses.

\section{Size distribution of culturable bacteria and fungi}

The size distribution of culturable bacteria and fungi in the three residential settings was highly variable in type I residences compared to types II and III. In type I the highest number of culturable bacteria were isolated from stage 1 ( $7 \mu \mathrm{m} \&$ above) in rooms and corridors, while stage $3(3.3-4.7 \mu \mathrm{m})$ dominated in kitchens and outdoors (Figure 1). A higher concentration in the coarse size fraction in living rooms and corridor reflects the presence of bioaerosols attached to a carrier matrix, most probably dust particles. The culturable fungi in kitchens, rooms, corridors and outdoors was greatest on stage $3(3.3-4.7 \mu \mathrm{m}), 5(1.1-2.1 \mu \mathrm{m}), 6(0.65-1.1 \mu \mathrm{m})$ and $4(2.1$ $3.3 \mu \mathrm{m}$ ), respectively (Figure 2).

In type II residences, both the kitchen and outdoors had a maximum culturable bacteria on stage $4(2.1-3.3 \mu \mathrm{m})$, while for living rooms stage 1 ( $7 \mu \mathrm{m} \&$ above) had the maximum number (Figure 3). For culturable fungi stage $6(0.65-1.1 \mu \mathrm{m})$ dominated in the kitchen, while for the living

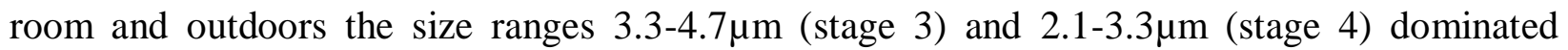
(Figure 4). 
In contrast, the culturable bacteria in mouldy type II residences were highest on stage 4 (2.1$3.3 \mu \mathrm{m})$ in kitchens and stage $3(3.3-4.7 \mu \mathrm{m})$ in living rooms. (Figure 5). The maximum concentration of culturable fungi in kitchens was on stage 3, while stage 4 was dominant in common rooms (Figure 6). The highest culturable bacteria was in the coarse size fraction in nonmouldy living room, contrary to mouldy living rooms where they were maximum in the respirable fraction.

The size distribution of culturable bacteria in type III residences revealed the dominance of stage $4(2.1-3.3 \mu \mathrm{m})$ in kitchens, although stage 1 ( $7 \mu \mathrm{m} \&$ above) had the major share in both living rooms and outdoors (Figure 7). Maximum culturable fungi was centred on stage $3(3.3-4.7 \mu \mathrm{m})$ outdoors and stage 1 ( $7 \mu \mathrm{m} \&$ above) in kitchens and living rooms (Figure 8).

On the other hand the size distribution of culturable bacteria and mould in kitchens and living rooms for type III residences with visible mould depicted the dominance of stage $3(3.3-4.7 \mu \mathrm{m})$

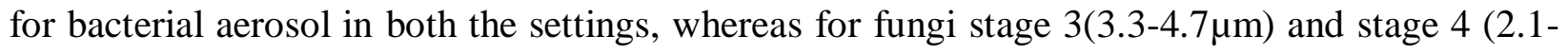
$3.3 \mu \mathrm{m})$ dominated in kitchens and living rooms, respectively (Figures 9 and 10).

The size distribution indicates that, in general, in the case of no evident indoor bioaerosol source (non-mouldy spaces), the size distribution peaks towards the coarse size fraction. This shows the presence of bioaerosols as agglomerates or attached to other non-biological matrixes rather than single cells. The species composition can also play a role in the size distribution. In mouldy or water damaged environments the bioaerosol composition would be different (Pasanen, 1992). The size of spores can be affected by dehydration, agglomeration and relative humidity of the surrounding air (Pasanen et al., 1991; Reponen et al., 1996; Ren et al., 2001). The hygroscopic growth of bioaerosols by condensation or water absorption, in naturally ventilated buildings, influences the kinetics of aerosols (Liao et al., 2004).

The size distribution of fungi during the present study is comparable to previously reported work. Several authors (Pastuszka et al., 2000; Reponen et al., 1994; Lin and Li, 1996; Zuraimi et al., 2009) found maximum fungal concentrations on stage $4(2.1 \mu \mathrm{m}-3.3 \mu \mathrm{m})$. During the present 
study maximum fungi was generally centred on stage 3 or 4 . However, in some cases it was highest on stage 5 and 6 as well.

Furthermore, the $\%$ of respirable bioaerosols $(<4.7 \mu \mathrm{m})$ indicates that more than half (in some cases 80 to $90 \%$ ) of culturable bacterial and fungal aerosol in both mouldy and non-mouldy residences were respirable and, hence, have the potential to penetrate into the lower respiratory system (Table 1). Li and Kuo (1993) found that in Taiwanese houses more than $80 \%$ of fungi were in the respirable fraction. Similarly, DeKoster and Throne (1995) reported that in American homes around $55 \%$ of total bacteria and $80 \%$ of total fungi were in the respirable fraction. According to Pastuszka et al. (2000) during the summer in Polish homes, $48 \%$ of total bacteria and $77 \%$ of total fungi were in the respirable fraction.

In type I the geometric average diameter, $\mathrm{dg}_{\text {ave }}$ was larger in the corridor for bacteria while for fungi it was smallest in corridor. Comparison of $\mathrm{dg}_{\mathrm{ave}}$ in type II and III mouldy and non-mouldy residences showed that the bacterial $\mathrm{dg}_{\mathrm{ave}}$ in mouldy residences was smaller in rooms and larger in kitchens than their respective non-mouldy settings. For fungi $\mathrm{dg}_{\text {ave }}$ was smaller in all the mouldy settings (except in kitchen for type II residences). Studies elsewhere have shown inconsistent results. Meklin et al. (2002) reported smaller $\mathrm{dg}_{\text {ave }}$ fungi for moisture damaged schools in comparison to those without moisture damage. Conversely, Reponen et al. (1994), Reponen (1995) and Zuraimi et al. (2009) showed larger fugal $\mathrm{dg}_{\mathrm{ave}}$ in moisture damaged buildings. Differences in use and management of residential space, mould infestation and dampness are the most likely explanations for the observed discrepancies.

\section{Conclusion}

During the present study it was found that indoor bioaerosol levels, both in total concentration and size distribution vary substantially within housing types in the same geographical region. The concentrations of culture bacteria in living rooms were higher in type II than type I and III houses and fungi was higher in type I than in type II and III houses. The concentrations of both culturable bacteria and fungi vary within the same house. During the present campaign the concentrations of both culturable bacteria and fungi were higher in type I and II houses and lower in type III concentrations in comparison to the summer campaign when it was double in 
type III accommodation as compared to type I and II. Mouldy houses had higher concentrations than non-mouldy houses in the same housing type. The size distribution of culturable bacteria and fungi was highly variable in type I residences compared to types II and III. In non-mouldy residences a considerable proportion of bioaerosols were found in coarse size. The observed differences in their concentration and the size distribution in different residential settings highlight the varied nature of respiratory exposure to the inhabitants of different residential settings. However an estimation of the health risk of bioaerosol exposure is difficult, mainly due to the lack of an established dose response relationship. There are no established threshold limits values for bioaerosols in indoor air. Some organisations have provided guidelines on the levels of indoor bioaerosols. At present the American Conference of Governmental Industrial Hygienists (ACGIH) does not provide any numerical guideline to indoor bioaerosols exposure. In 1994, the New York City Department of Health, in their guidelines for assessment and remediation of indoor fungal contamination, stated that "it is not possible to determine "safe" or "unsafe" levels of exposure..." (NYC-DOH, 1994). In Canada, a committee on Environmental and Occupational Health by Health Canada developed the following guidelines. More than 50 $\mathrm{CFU} / \mathrm{m}^{3}$ of a single species (other than Cladosporium or Alternaria) require investigation. The presence of fungal pathogen is not acceptable. Up to $150 \mathrm{CFU} / \mathrm{m}^{3}$ is normal for a mixture of species and correspond to outdoor species composition. Up to $500 \mathrm{CFU} / \mathrm{m} 3$ is acceptable in summer if the species are mainly Cladosporium or other tree and leaf fungi. (Health Canada, 1995). The Commission of the European Communities has also suggested that available knowledge is not enough to set threshold limit values for the presence of airborne bacteria and fungi in indoor environments (CEC, 1993). It is of note that the levels of bioaerosol reported in this study were for culturable bioaerosol on selective media and many viable cells may not grow on this media. This could lead to an underestimation of the total exposure (Swan et al., 2003). Furthermore non-viable cells can have important health impacts due to toxigenic and allergenic components such as endotoxins, glucans and mycotoxins. Hence the actual exposure to bioaerosol and their components would be far greater than currently estimated, in particular to children and elderly due to their vulnerability and increased exposure duration due to amount of time spent indoors.

\section{References}


ACGIH, 1999. Bioaerosols: Assessment and Control. American Conference of Governmental Industrial Hygienists, Cincinnati, Ohio.

Buttner, M.P., Stetzenbach, L.D., 1993. Monitoring airborne fungal spores in an experimental indoor environment to evaluate sampling methods and the effects of human activity on air sampling. Applied and Environmental Microbiology 59, 219-226.

CEC, 1993. Biological particles in indoor environments. Office for Official Publications of the European Communities.

Dekoster, J.A., Thorne, P.S., 1995. Bioaerosol concentrations in noncomplaint, complaint, and intervention homes in the Midwest. American Industrial Hygiene Association Journal 56, 573580.

Fabian, M.P., Miller, S.L., Reponen, T., Hernandez, M.T., 2005. Ambient bioaerosol indices for indoor air quality assessments of flood reclamation. Journal of Aerosol Science 36, 763-783.

Gorny, R.L., Dutkiewicz, J., 2002. Bacterial and fungal aerosols in indoor environment in Central and Eastern European countries. Annals of Agricultural and Environmental Medicine 9, 17-23.

Gorny, R.L., Dutkiewicz, J., Krysinska-Traczyk, E., 1999. Size distribution of bacterial and fungal bioaerosols in indoor air. Ann Agric Environ Med 6, 105-113.

Green, C.F., Scarpino, P.V., Gibbs, S.G., 2003. Assessment and modeling of indoor fungal and bacterial bioaerosol concentrations. Aerobiologia 19, 159-169.

Haas, D., Habib, J., Galler, H., Buzina, W., Schlacher, R., Marth, E., Reinthaler, F.F., 2007. Assessment of indoor air in Austrian apartments with and without visible mold growth. Atmospheric Environment 41, 5192-5201.

Health Canada, 1995. Exposure Guidelines for Residential Indoor Air Quality: A Report of the Federal-Provincial Advisory Committee on Environmental and Occupational Health, Ottawa.

Hunter, C.A., Grant, C., Flannigan, B., Bravery, A.F., 1988. Mould in buildings: the air spora of domestic dwellings. International Biodeterioration \& Biodegradation 24, 81-101.

Hunter, C.A., Hull, A.V., Higham, D.F., Grimes, C.P., Lea, R.G., 1996. Fungi and Bacteria, in: Berry, R.W., Brown, V.M., Coward, S.K.D., Crump, D.R., Gavin, M., Grimes, C.P., Higham, D.F., Hull, A.V., Hunter, C.A., Jeffery, I.G., Lea, R.G., Llewellyn, J.W., Raw, G.J. (Eds.), Indoor air quality in homes: part 1. Building Research Establishment, Garston, pp. 97-115.

Hyvarinen, A., Reponen, T., Husman, T., Ruuskanen, J., Nevalainen, A., 1993. Characterizing mold problem buildings-concentrations and flora of viable fungi. Indoor Air 3, 337-343.

Hyvarinen, A., Vahteristo, M., Meklin, T., Jantunen, M., Nevalainen, A., Moschandreas, D., 2001. Temporal and spatial variation of fungal concentrations in indoor air. Aerosol Science and Technology 35, 688-695.

Jones, A.M., Harrison, R.M., 2004. The effects of meteorological factors on atmospheric bioaerosol concentrations - a review. Science of the Total Environment 326, 151-180. 
Kalogerakis, N., Paschali, D., Lekaditis, V., Pantidou, A.,Eleftheriadis, K. and Lazaridis, M., 2005. Indoor Air Quality - Bioaerosol measurements in domestic and office premises. Journal of Aerosol Science 36, 751-761.

Kulmala, M., Asmi, A., Pirjola, L., 1999. Indoor air aerosol model: the effect of outdoor air, filtration and ventilation on indoor concentrations. Atmospheric Environment 33, 2133-2144.

Lee, J.H., Jo, W.K., 2006. Characteristics of indoor and outdoor bioaerosols at Korean high-rise apartment buildings. Environmental Research 101, 11-17.

Lee, T., Grinshpun, S.A., Martuzevicius, D., Adhikari, A., Crawford, C.M., Reponen, T., 2006. Culturability and concentration of indoor and outdoor airborne fungi in six single-family homes. Atmospheric Environment 40, 2902-2910.

Levetin, E., Shaughnessy, R., Fisher, E., Ligman, B., Harrison, J., Brennan, T., 1995. Indoor air quality in schools: exposure to fungal allergens. Aerobiologia 11, 27-34.

Li, C.S., Kuo, T.M., 1993. Microbiological indoor air quality in subtropical areas. Environment international 19, 233-239.

Liao, C.M., Luo, W.C., Chen, S.C., Chen, J.W., Liang, H.M., 2004. Temporal/seasonal variations of size-dependent airborne fungi indoor/outdoor relationships for a wind-induced naturally ventilated airspace. Atmospheric Environment 38, 4415-4419.

Lin, W.H., Li, C.S., 1996. Size characteristics of fungus allergens in the subtropical climate. Aerosol Science and Technology 25, 93-100.

Macher, J.M., Huang, F.Y., Flores, M., 1991. A 2-year study of microbiological indoor airquality in a new apartment. Archives of Environmental Health 46, 25-29.

Medrela-Kuder, E., 2003. Seasonal variations in the occurrence of culturable airborne fungi in outdoor and indoor air in Cracow. International Biodeterioration \& Biodegradation 52, 203-205.

Meklin, T., Hyvarinen, A., Toivola, M., Reponen, T., Koponen, V., Husman, T., Taskinen, T., Korppi, M., Nevalainen, A., 2003. Effect of building frame and moisture damage on microbiological indoor air quality in school buildings. Aiha Journal 64, 108-116.

Meklin, T., Reponen, T., Toivola, M., Koponen, V., Husman, T., Hyvarinen, A., Nevalainen, A., 2002. Size distributions of airborne microbes in moisture-damaged and reference school buildings of two construction types. Atmospheric Environment 36, 6031-6039.

Mentese, S., Arisoy, M., Rad, A.Y., Güllü, G., 2009. Bacteria and fungi levels in various indoor and outdoor environments in Ankara, Turkey. CLEAN-Soil, Air, Water 37, 487-493.

Miller, J.D., Haisley, P.D., Reinhardt, J.H., 2000. Air sampling results in relation to extent of fungal colonization of building materials in some water-damaged buildings. Indoor AirInternational Journal of Indoor Air Quality and Climate 10, 146-151.

Morris, K. J. 1995. Modern Microscopic Methods of Bioaerosol Analysis, In Bioaerosols Handbook C. S. Cox and C. M. Wathes (Eds) page 285. CRC Press, ISBN 1-87371-615-9

Nasir, Z.A., Colbeck, I., 2010. Assessment of Bacterial and Fungal Aerosol in Different Residential Settings. Water Air and Soil Pollution 211, 367-377. 
Water, Air, \& Soil Pollution 223 (2012) pp.5613-5622

Nevalainen, A., Pasanen, A.L., Niininen, M., Reponen, T., Kalliokoski, P., Jantunen, M.J., 1991. The indoor air-quality in Finnish homes with mold problems. Environment International 17, 299302.

NYC-DOH, 1994. Guidelines on assessment and remediation of fungi in indoor environments.

Pasanen, A.L., 1992. Airborne mesophilic fungal spores in various residential environments. Atmospheric Environment Part a-General Topics 26, 2861-2868.

Pasanen, A.L., Kasanen, J.P., Rautiala, S., Ikaheimo, M., Rantamaki, J., Kaariainen, H., Kalliokoski, P., 2000. Fungal growth and survival in building materials under fluctuating moisture and temperature conditions. International Biodeterioration \& Biodegradation 46, 117 127.

Pasanen, A.L., Pasanen, P., Jantunen, M.J., Kalliokoski, P., 1991. Significance of air humidity and air velocity for fungal spore release into the air. Atmospheric Environment Part a-General Topics 25, 459-462.

Pastuszka, J.S., Paw, U.K.T., Lis, D.O., Wlazlo, A., Ulfig, K., 2000. Bacterial and fungal aerosol in indoor environment in Upper Silesia, Poland. Atmospheric Environment 34, 3833-3842.

Pessi, A.M., Suonketo, J., Pentti, M., Kurkilahti, M., Peltola, K., Rantio-Lehtimaki, A., 2002. Microbial growth inside insulated external walls as an indoor air biocontamination source. Applied and Environmental Microbiology 68, 963-967.

Raisi, L., Lazaridis, M., Katsivela, E. 2010. Relationship between airborne microbial and particulate matter concentrations in the ambient air at a Mediterranean site. Global NEST Journal $12,84-91$

Ren, P., Jankun, T.M., Belanger, K., Bracken, M.B., Leaderer, B.P., 2001. The relation between fungal propagules in indoor air and home characteristics. Allergy 56, 419-424.

Ren, P., Jankun, T.M., Leaderer, B.P., 1999. Comparisons of seasonal fungal prevalence in indoor and outdoor air and in house dusts of dwellings in one Northeast American county. Journal of Exposure Analysis and Environmental Epidemiology 9, 560-568.

Reponen, T., 1995. Aerodynamic diameters and respiratory deposition estimates of viable fungal particles in mold problem dwellings. Aerosol Science and Technology 22, 11-23.

Reponen, T., Hyvarinen, A., Ruuskanen, J., Raunemaa, T., Nevalainen, A., 1994. Comparison of concentrations and size distributions of fungal spores in buildings with and without mold problems. Journal of Aerosol Science 25, 1595-1603.

Reponen, T., Willeke, K., Ulevicius, V., Reponen, A., Grinshpun, S.A., 1996. Effect of relative humidity on the aerodynamic diameter and respiratory deposition of fungal spores. Atmospheric Environment 30, 3967-3974.

Salonen, H., Lappalainen, S., Lindroos, O., Harju, R., Reijula, K., 2007. Fungi and bacteria in mould-damaged and non-damaged office environments in a subarctic climate. Atmospheric Environment 41, 6797-6807.

Shelton, B.G., Kirkland, K.H., Flanders, W.D., Morris, G.K., 2002. Profiles of airborne fungi in buildings and outdoor environments in the United States. Applied and Environmental Microbiology 68, 1743-1753. 
Strachan, D.P., Flannigan, B., McCabe, E.M., McGarry, F., 1990. Quantification of airborne molds in the homes of children with and without wheeze. Thorax 45, 382-387.

Swan, J., Gilbert, E., Kelsey, A., Crook, B., 2003. Occupational and environmental exposure to bioaerosols from composts and potential health effects- a critical review of published data. HSE Report RR130.

Verhoeff, A.P., Vanwijnen, J.H., Brunekreef, B., Fischer, P., Vanreenenhoekstra, E.S., Samson, R.A., 1992. Presence of viable mold propagules in indoor air in relation to house damp and outdoor air. Allergy 47, 83-91.

Viitanen, H., Hanhijärvi, A., Hukka, A., Koskela, K., 2000. Modelling mould growth and decay damages, Healthy Buildings, Espoo, pp. 341-346.

Waegemaekers, M., Vanwageningen, N., Brunekreef, B., Boleij, J.S.M., 1989. Respiratory symptoms in damp homes - a pilot-study. Allergy 44, 192-198.

World Health Organization, 2009. WHO guidelines for indoor air quality: dampness and mould. WHO.

Zuraimi, M.S., Fang, L., Tan, T.K., Chew, F.T., Tham, K.W., 2009. Airborne fungi in low and high allergic prevalence child care centers Atmospheric Environment 43, 2391-2400. 
Water, Air, \& Soil Pollution 223 (2012) pp.5613-5622

Table 1. Geometric mean (GM), geometric standard deviation (GSD), range, average geometric mean diameter $\left(\mathrm{dg}_{\mathrm{ave}}\right)$ and $\%$ of less than $4.7 \mu \mathrm{m}$ of total culturable fungal and bacterial aerosol for three different housing types

\begin{tabular}{|c|c|c|c|c|c|c|c|c|}
\hline \multicolumn{9}{|c|}{ Type I residences $(n=8)$} \\
\hline & \multicolumn{4}{|c|}{ Bacteria } & \multicolumn{4}{|c|}{ Fungi } \\
\hline & Kitchen & Room & Corridor & Outdoor & Kitchen & Room & Corridor & Outdoor \\
\hline $\begin{array}{l}\text { Total GM } \\
\left(\mathrm{CFU} / \mathrm{m}^{3}\right)\end{array}$ & 2793 & 2200 & 3171 & 687 & 1173 & 1198 & 1281 & 491 \\
\hline $\begin{array}{c}\text { Range } \\
\left(\mathrm{CFU} / \mathrm{m}^{3}\right)\end{array}$ & $\begin{array}{c}1557- \\
5017\end{array}$ & $\begin{array}{l}282- \\
3922\end{array}$ & $\begin{array}{c}2137- \\
4540\end{array}$ & $\begin{array}{l}424- \\
1113\end{array}$ & $\begin{array}{l}618- \\
2226\end{array}$ & $\begin{array}{c}229- \\
12067\end{array}$ & $\begin{array}{l}936- \\
1696\end{array}$ & $\begin{array}{l}318- \\
759\end{array}$ \\
\hline GSD & 2.28 & 2.1 & 1.45 & 1.97 & 2.47 & 2.59 & 1.34 & 1.85 \\
\hline $\operatorname{dg}_{\text {ave }}(\mu \mathrm{m})$ & 3.27 & 3.77 & 4.42 & 3.11 & 3.62 & 2.20 & 1.83 & 3.77 \\
\hline$\%<4.7 \mu \mathrm{m}$ & 65 & 60 & 54 & 64 & 68 & 79 & 77 & 65 \\
\hline \multicolumn{9}{|c|}{ Type $I I$ residences $(n=10)$} \\
\hline $\begin{array}{l}\text { Total GM } \\
\left(\mathrm{CFU} / \mathrm{m}^{3}\right)\end{array}$ & 886 & 3487 & $*$ & 370 & 467 & 833 & $*$ & 229 \\
\hline $\begin{array}{c}\text { Range } \\
\left(\mathrm{CFU} / \mathrm{m}^{3}\right)\end{array}$ & $\begin{array}{l}618- \\
1272\end{array}$ & $\begin{array}{c}1855- \\
6554\end{array}$ & $*$ & $\begin{array}{c}353- \\
388\end{array}$ & $\begin{array}{c}353- \\
618\end{array}$ & $\begin{array}{l}689- \\
4007\end{array}$ & $*$ & $\begin{array}{c}212- \\
247\end{array}$ \\
\hline GSD & 1.66 & 2.44 & $*$ & 1.06 & 1.18 & 1.30 & $*$ & 1.11 \\
\hline $\operatorname{dg}_{\text {ave }}(\mu \mathrm{m})$ & 3.17 & 6.15 & $*$ & 3.72 & 1.65 & 3.98 & $*$ & 2.08 \\
\hline$\%<4.7 \mu \mathrm{m}$ & 86 & 35 & $*$ & 59 & 83 & 63 & $*$ & 84 \\
\hline \multicolumn{9}{|c|}{ Type II residences(Mouldy) $(n=2)$} \\
\hline $\begin{array}{l}\text { Total GM } \\
\left(\mathrm{CFU} / \mathrm{m}^{3}\right)\end{array}$ & 5211 & 4461 & $*$ & $*$ & 4796 & 3462 & $*$ & $*$ \\
\hline $\begin{array}{c}\text { Range } \\
\left(\mathrm{CFU} / \mathrm{m}^{3}\right)\end{array}$ & $\begin{array}{c}5158- \\
5265\end{array}$ & $\begin{array}{c}4434- \\
4487\end{array}$ & $*$ & $*$ & $\begin{array}{c}4787- \\
4805\end{array}$ & $\begin{array}{c}3445- \\
3480\end{array}$ & $*$ & $*$ \\
\hline GSD & 1.01 & 1 & $*$ & $*$ & 1 & 1 & $*$ & $*$ \\
\hline $\mathrm{dg}_{\mathrm{ave}}(\mu \mathrm{m})$ & 3.49 & 3.86 & $*$ & $*$ & 2.69 & 3.57 & $*$ & $*$ \\
\hline$\%<4.7 \mu \mathrm{m}$ & 78 & 72 & $*$ & $*$ & 91 & 76 & $*$ & $*$ \\
\hline \multicolumn{9}{|c|}{ Type III residences $(n=8)$} \\
\hline $\begin{array}{l}\text { Total GM } \\
\left(\mathrm{CFU} / \mathrm{m}^{3}\right)\end{array}$ & 1346 & 1361 & $*$ & 391 & 280 & 195 & $*$ & 214 \\
\hline $\begin{array}{c}\text { Range } \\
\left(\mathrm{CFU} / \mathrm{m}^{3}\right)\end{array}$ & $\begin{array}{l}653- \\
2773\end{array}$ & $\begin{array}{l}530- \\
3498\end{array}$ & $*$ & $\begin{array}{c}247- \\
618\end{array}$ & $\begin{array}{c}212- \\
371\end{array}$ & $\begin{array}{l}53- \\
724\end{array}$ & $*$ & $\begin{array}{c}123- \\
371\end{array}$ \\
\hline GSD & 3.77 & 3.79 & $*$ & 1.91 & 1.48 & 6.35 & $*$ & 2.17 \\
\hline $\operatorname{dg}_{\text {ave }}(\mu \mathrm{m})$ & 2.53 & 4.11 & $*$ & 4.48 & 4.47 & 3.54 & $*$ & 4.22 \\
\hline$\%<4.7 \mu \mathrm{m}$ & 90 & 53 & $*$ & 51 & 57 & 54 & $*$ & 67 \\
\hline \multicolumn{9}{|c|}{ Type III residences (Mouldy $(n=2)$} \\
\hline $\begin{array}{l}\text { Total GM } \\
\left(\mathrm{CFU} / \mathrm{m}^{3}\right)\end{array}$ & 29258 & 22772 & $*$ & $*$ & 23780 & 28701 & $*$ & $*$ \\
\hline $\begin{array}{c}\text { Range } \\
\left(\mathrm{CFU} / \mathrm{m}^{3}\right)\end{array}$ & $\begin{array}{c}28568 \\
- \\
29964\end{array}$ & $\begin{array}{c}22102- \\
23462\end{array}$ & $*$ & $*$ & $\begin{array}{c}22102- \\
23462\end{array}$ & $\begin{array}{r}28003- \\
29416\end{array}$ & $*$ & $*$ \\
\hline GSD & 1.03 & 1.04 & $*$ & $*$ & 1.04 & 1.03 & $*$ & $*$ \\
\hline
\end{tabular}


Water, Air, \& Soil Pollution 223 (2012) pp.5613-5622

\begin{tabular}{|c|c|c|c|c|c|c|c|c|}
\hline $\mathrm{dg}_{\mathrm{ave}}(\mu \mathrm{m})$ & 3.93 & 3.55 & $*$ & $*$ & 3.55 & 2.07 & $*$ & $*$ \\
\hline$\%<4.7 \mu \mathrm{m}$ & 59 & 68 & $*$ & $*$ & 68 & 81 & $*$ & $*$ \\
\hline
\end{tabular}

$\mathrm{n}=$ (Number of samples)

Table 2. Temperature $\left({ }^{\circ} \mathrm{C}\right)$, relative humidity $(\%)$ and their standard deviation values in three different housing types

\begin{tabular}{|l|c|c|c|c|c|c|c|c|}
\hline & \multicolumn{4}{|c|}{ Temperature $\left({ }^{\circ} \mathrm{C}\right)$} & \multicolumn{4}{c|}{ Relative Humidity (\%) } \\
\hline & \multicolumn{2}{|c|}{ Indoor } & \multicolumn{2}{c|}{ Outdoor } & \multicolumn{3}{c|}{ Indoor } & \multicolumn{2}{c|}{ Outdoor } \\
\hline & Mean & SD & Mean & SD & Mean & SD & Mean & SD \\
\hline Type I $(n=8)$ & 20 & 2 & 12 & 1.5 & 38 & 11 & 61 & 5 \\
\hline Type II $(n=10)$ & 21 & 1.09 & 12 & 1.5 & 50 & 9 & 58 & 4 \\
\hline $\begin{array}{l}\text { Type II(Mouldy) } \\
(n=2)\end{array}$ & 19 & 1.5 & 13 & 2 & 66 & 2 & 57 & 3 \\
\hline Type III (n=8) & 20 & 1.5 & 12 & 2 & 37 & 11 & 60 & 7 \\
\hline $\begin{array}{l}\text { Type III (Mouldy) } \\
(n=2)\end{array}$ & 20 & 2 & 11 & 2 & 60 & 2 & 62 & 4 \\
\hline
\end{tabular}

$\mathrm{n}=$ (Number of samples) 


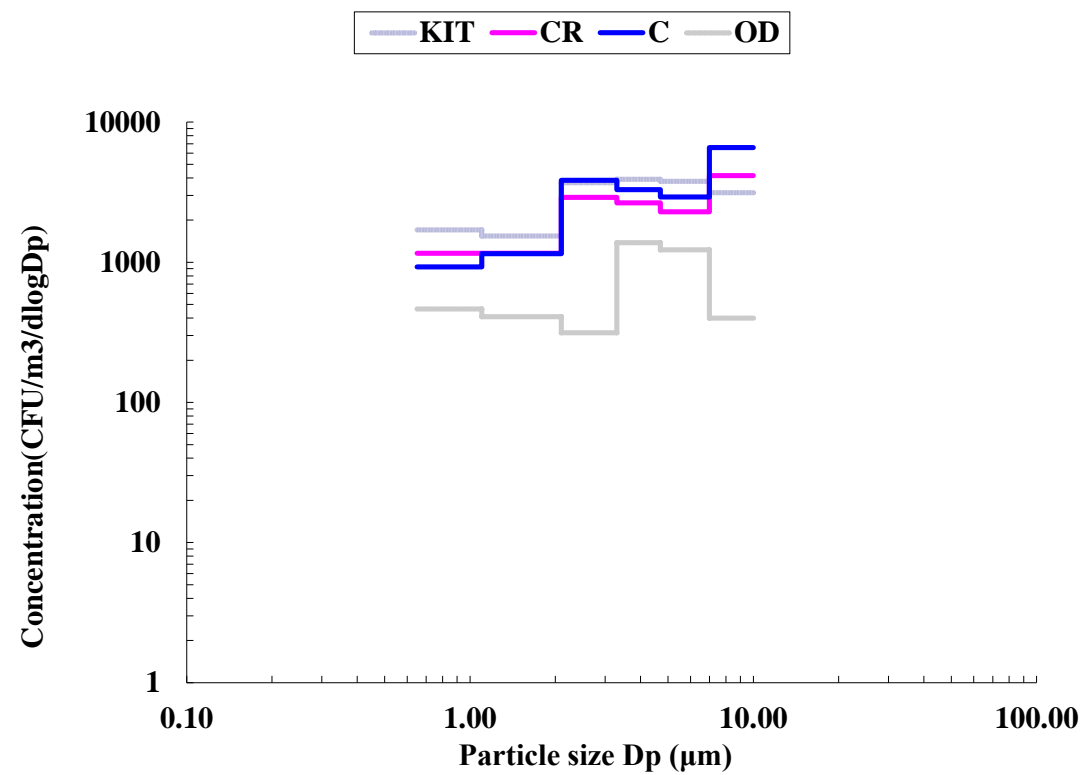

Figure1 .Size distribution of culturable total bacterial aerosol in kitchens (KIT), living rooms $(\mathrm{CR})$, corridors $(\mathrm{C})$ and outdoors (OD) in Type I residences.

$$
-\mathbf{K I T}-\mathbf{C R}-\mathbf{C}-\mathbf{O D}
$$

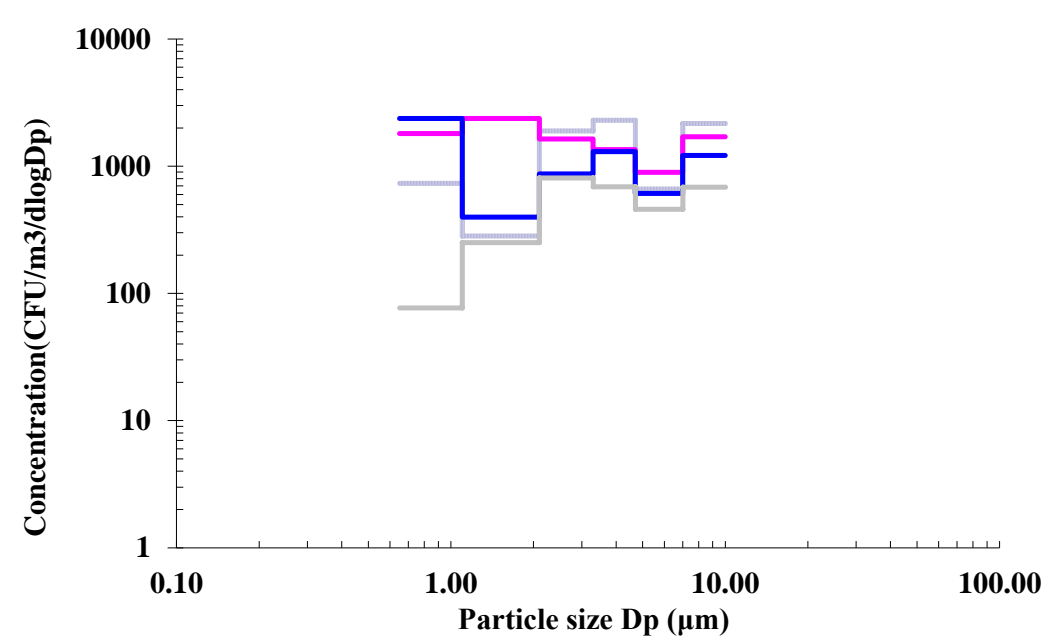

Figure 2.Size distribution of culturable total fungal aerosol in kitchens (KIT), living rooms (CR), corridors $(\mathrm{C})$ and outdoors (OD) in Type I residences. 


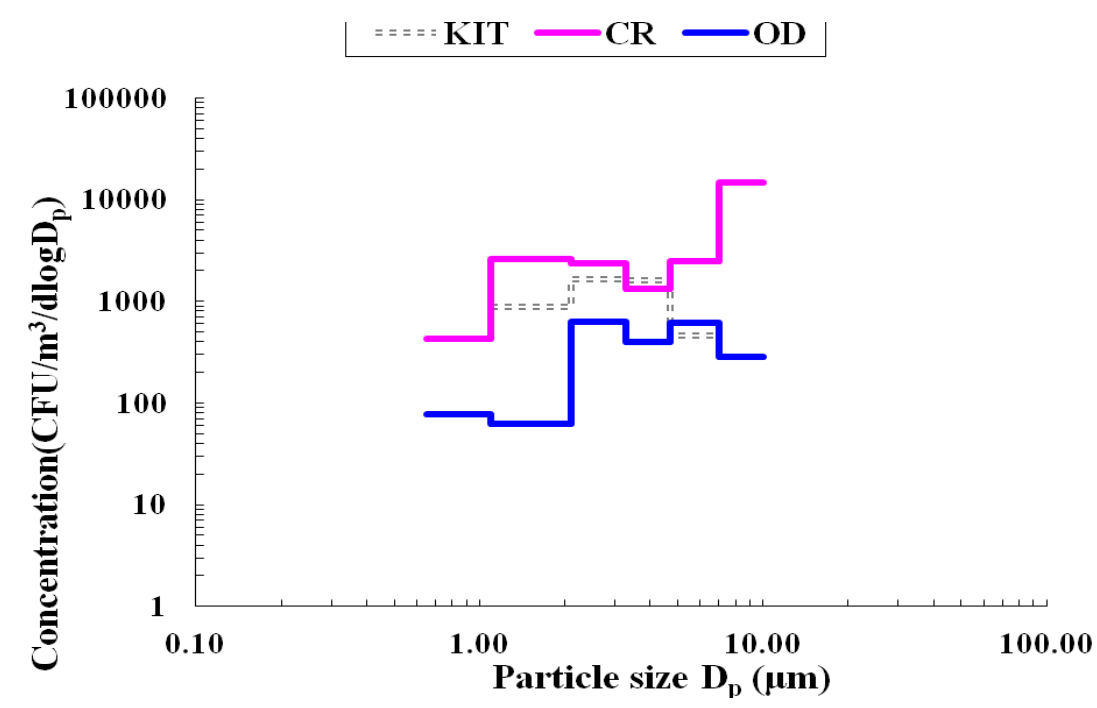

Figure 3 .Size distribution of culturable total bacterial aerosol in kitchens (KIT), living rooms (CR) and outdoors (OD) in Type II residences.

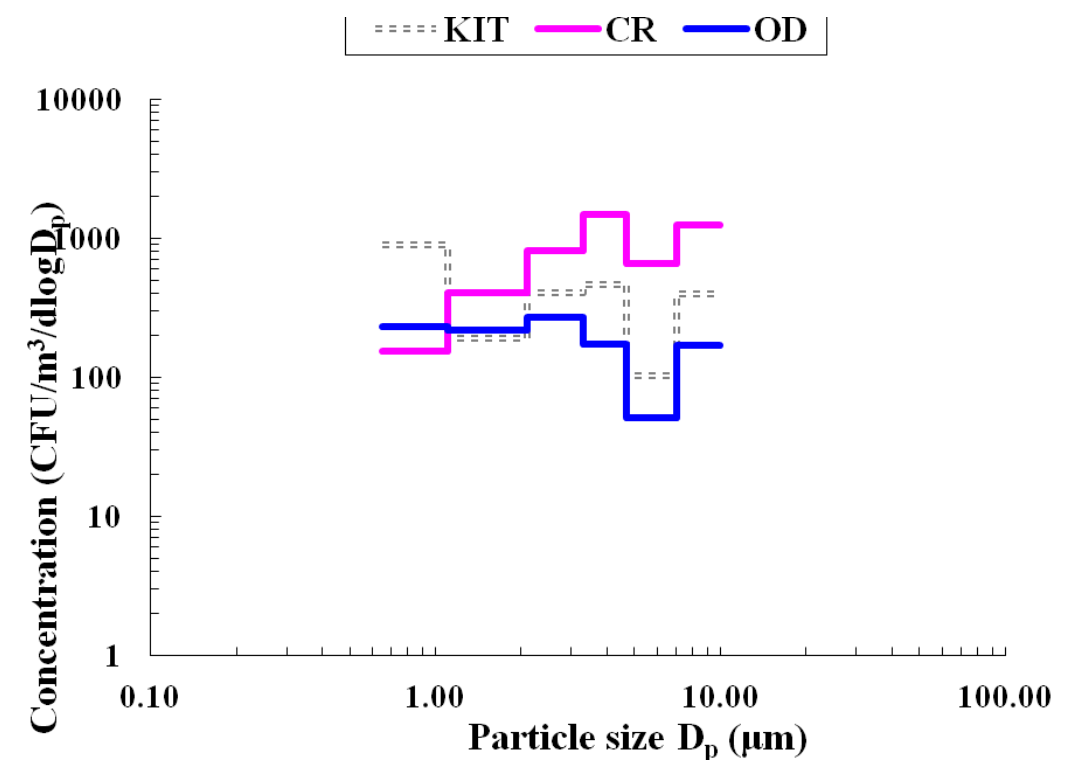

Figure 4 .Size distribution of culturable total fungal aerosol in kitchens (KIT), living rooms (CR) and outdoors (OD) in Type II residences 


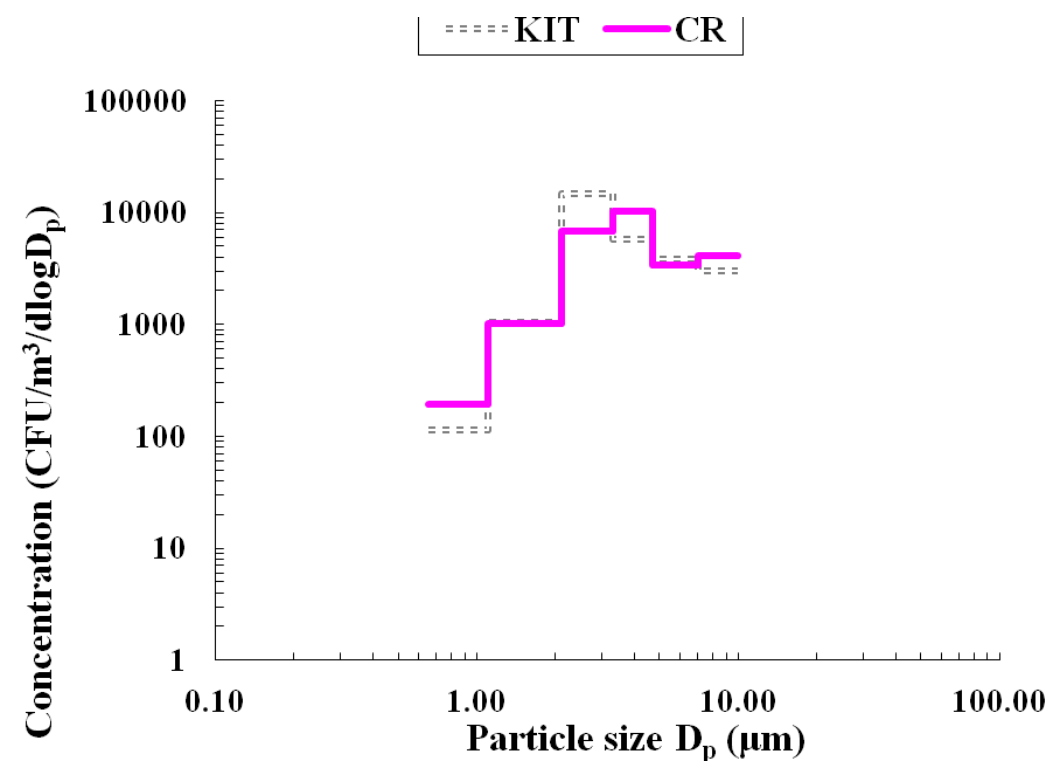

Figure 5. Size distribution of culturable total bacterial aerosol in kitchens (KIT) and living rooms (CR) in Type II mouldy residences.

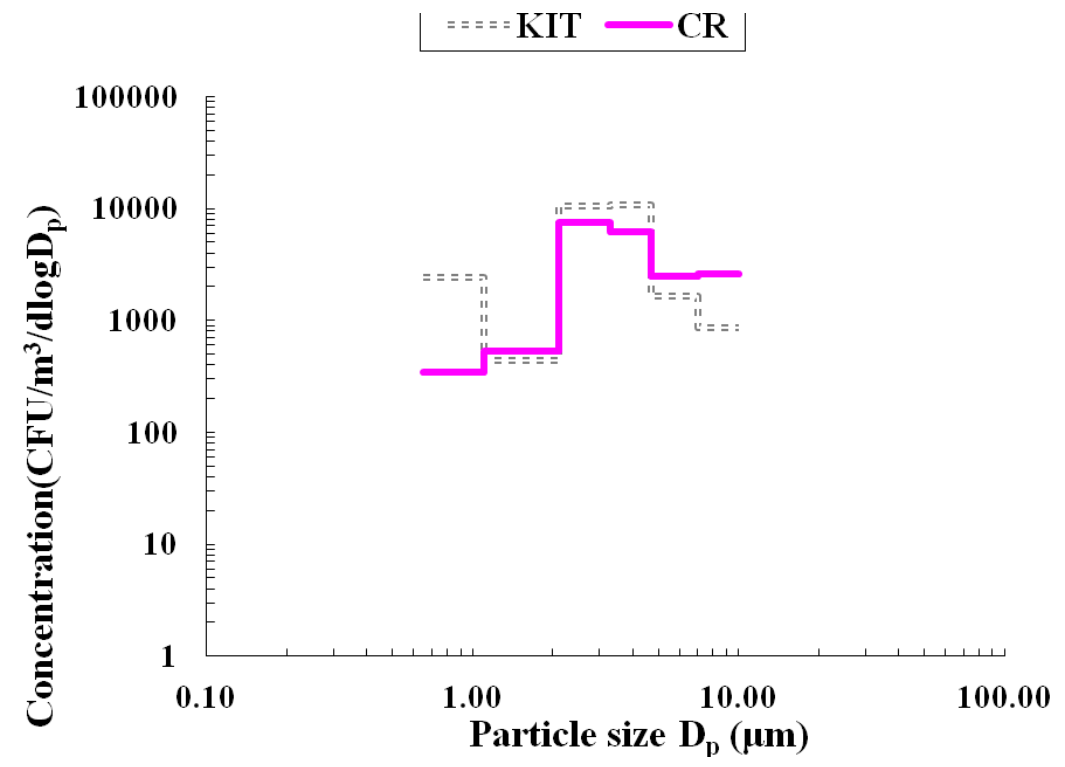

Figure 6 .Size distribution of culturable total fungal aerosol in kitchens (KIT) and living rooms (CR) in Type II mouldy residences 


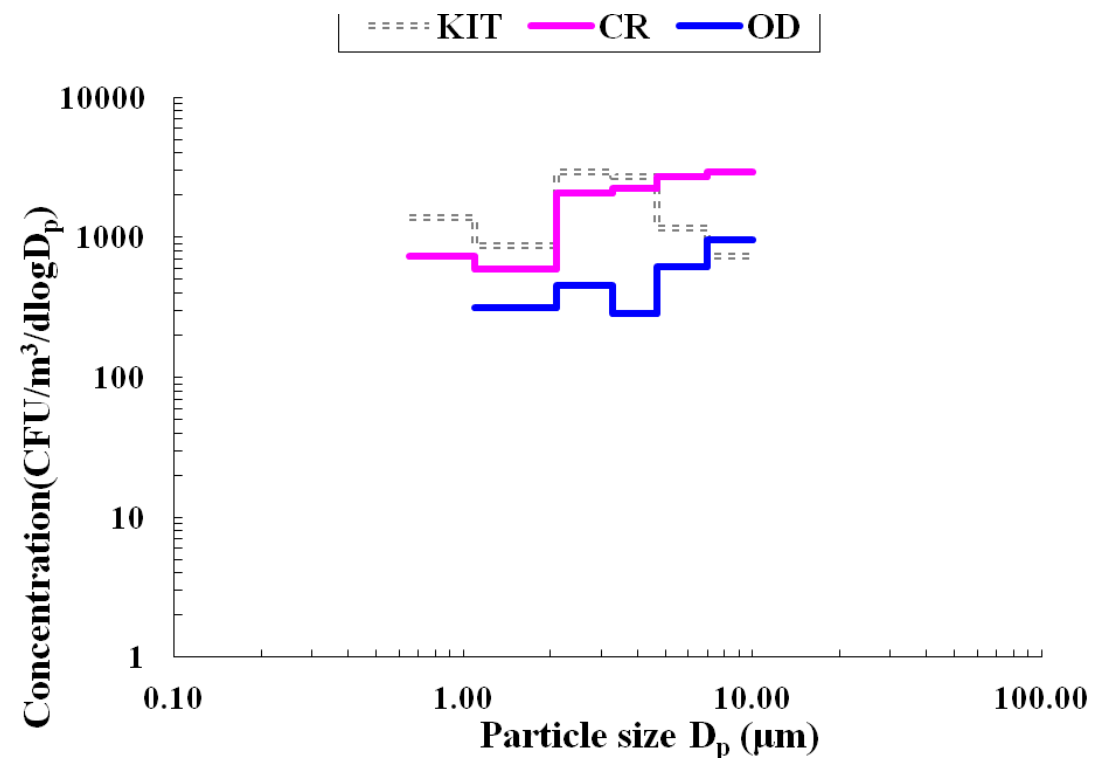

Figure 7 .Size distribution of culturable total bacterial aerosol in kitchens (KIT), living rooms (CR) and outdoors (OD) in Type III residences.

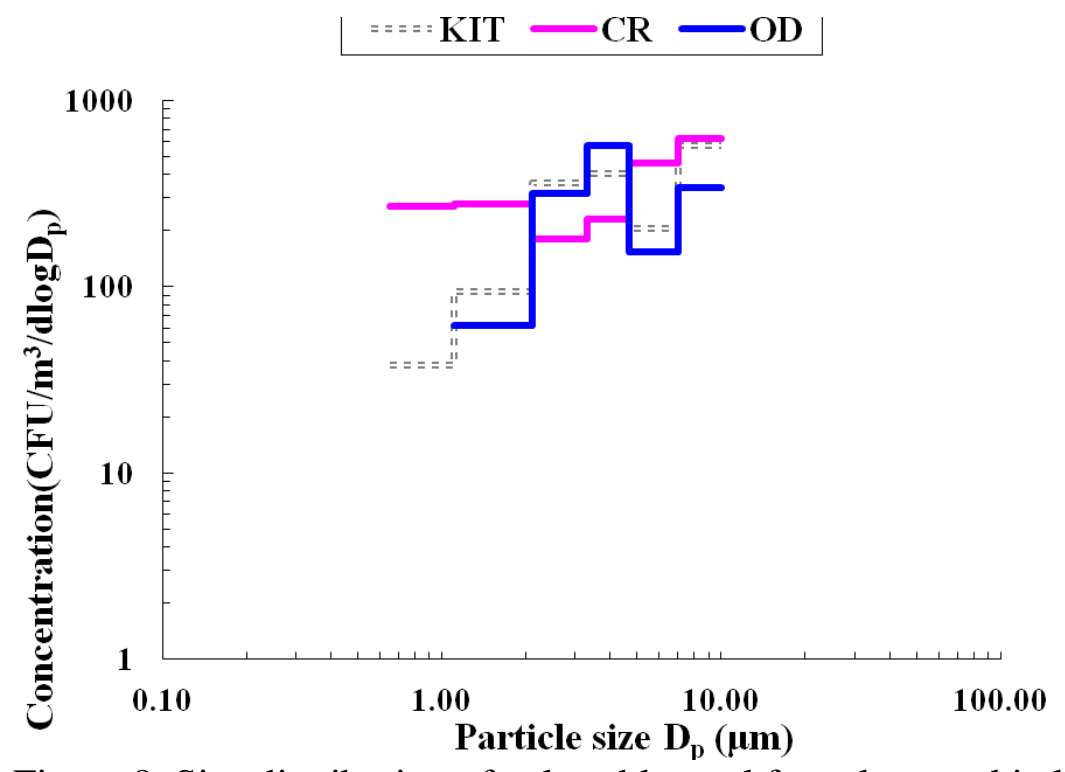

Figure 8 .Size distribution of culturable total fungal aerosol in kitchens (KIT), living rooms (CR) and outdoors (OD) in Type III residences 


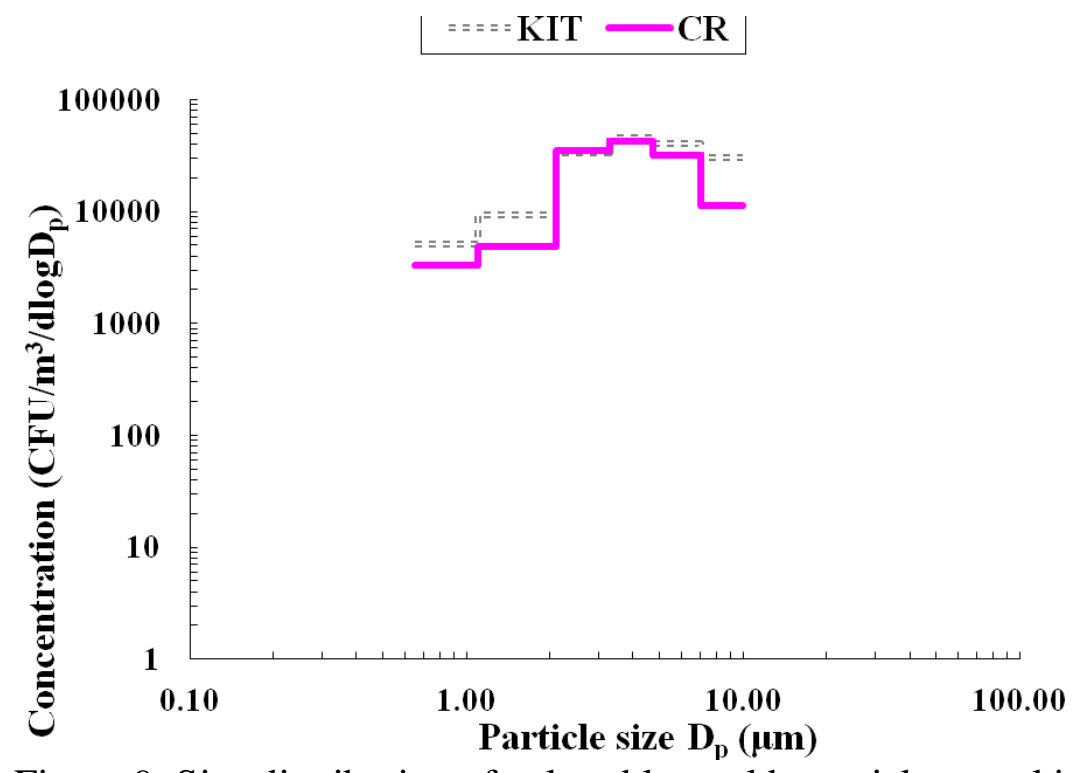

Figure 9 .Size distribution of culturable total bacterial aerosol in kitchens (KIT) and living rooms (CR) in Type III mouldy residences.

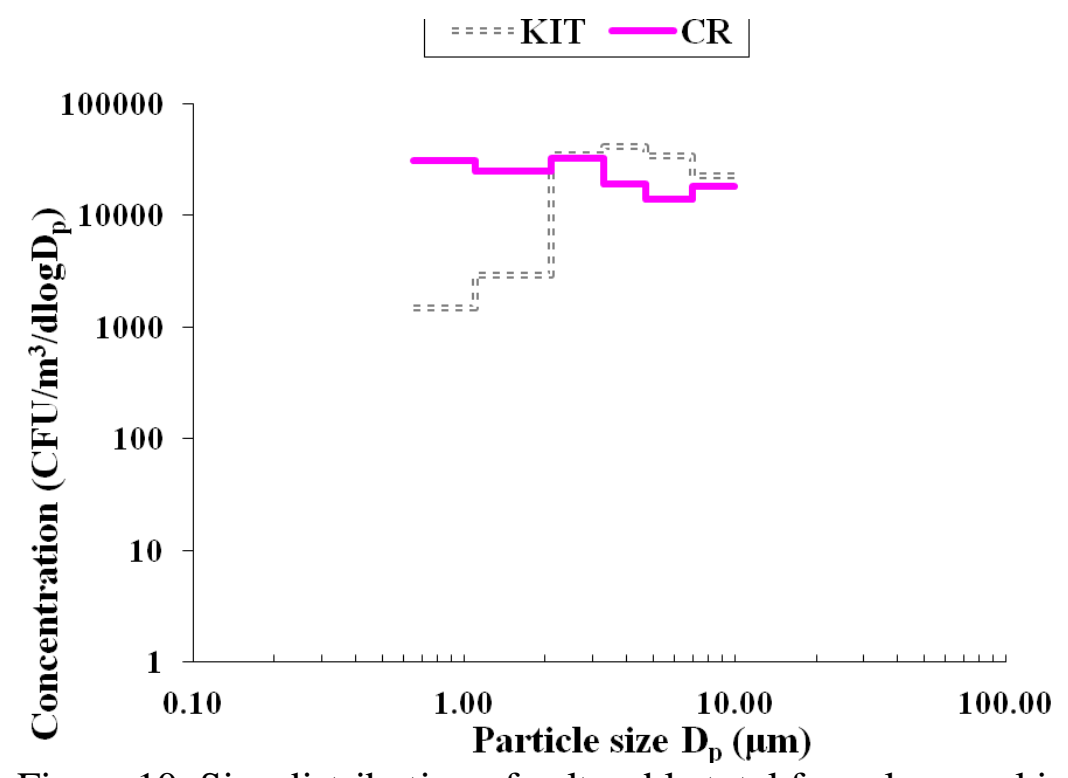

Figure 10 .Size distribution of culturable total fungal aerosol in kitchens (KIT) and living rooms (CR) in Type III mouldy residences. 